TAPROBANICA, ISSN 1800-427X. October, 2011. Vol. 03, No. 02: pp. 102-103.

(C) Taprobanica Private Limited, Jl. Kuricang 18 Gd.9 No.47, Ciputat 15412, Tangerang, Indonesia.

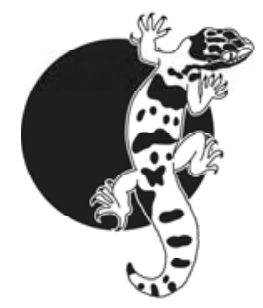

\section{First record of banded krait (Bungarus fasciatus) from Pilibhit District, Uttar Pradesh - India}

The banded krait, Bungarus fasciatus (Schneider, 1801) is one of the venomous elapids of the genus Bungarus Daudin, 1803, widely distributed in South and South-East Asia. It bears conspicuous equally spaced, wide yellow or pale brown and black bands. Uppermost scales on the back are hexagonal in shape and overall scales are glossy in appearance. Its head is slightly broader than neck and eyes entirely black. This snake is nocturnal in habit and prefers open plain areas (Whitaker \& Captain, 2004). The snout is bluntly rounded. On the top of the head there is yellow ' $\mathrm{V}$ ', the arms of which diverge backwards and passes over the temples to the throat. The crown is black except lips and lore which are yellow in colour. The triangular body shape in cross-section, bluntly ending finger like tail and peculiar banding pattern are the prominent identification keys to distinguish this snake. The young broods bear more pointed tails than adults and a modified colouring, the yellow colour being replaced by dirty white and the black colour by leaden hue. This snake is reported to be sluggish and timid even in the presence of provocation but able to devour other snakes, sometimes longer than its own body length (Wall, 1910 \& 1912).

In India, the banded krait is documented from north-eastern states, West Bengal, Orissa, Bihar (Smith, 1911), Jharkhand, Chattisgarh, parts of Maharashtra, Madhya Pradesh, Andhra Pradesh (Kinnear, 1913; Srinivasulu et al., 2009) and eastern part of Uttar Pradesh (Daniel, 2002; Deodars, 1978; Murthy, 2010; Sharma, 2003; Wall 1912; Whitaker \& Captain, 2004). In the present communication, a banded krait was reported from the western most part of Terai of Uttar Pradesh. Banded krait has been reported from Gorakhpur (Masson, 1929), Bahraich and Kheri districts (Martin, 1913) while it was not recorded from Fyzabad (Wall, 1907) and Benaras Districts
(Acharji, 1946) of Uttar Pradesh. A well grown individual about $1 \mathrm{~m}$ on the basis of ocular estimation (Fig. 1) was sighted crossing the metalledroad near Mahof range of Pilibhit forest division at 20:55 hr on 15 ${ }^{\text {th }}$ June, 2010.

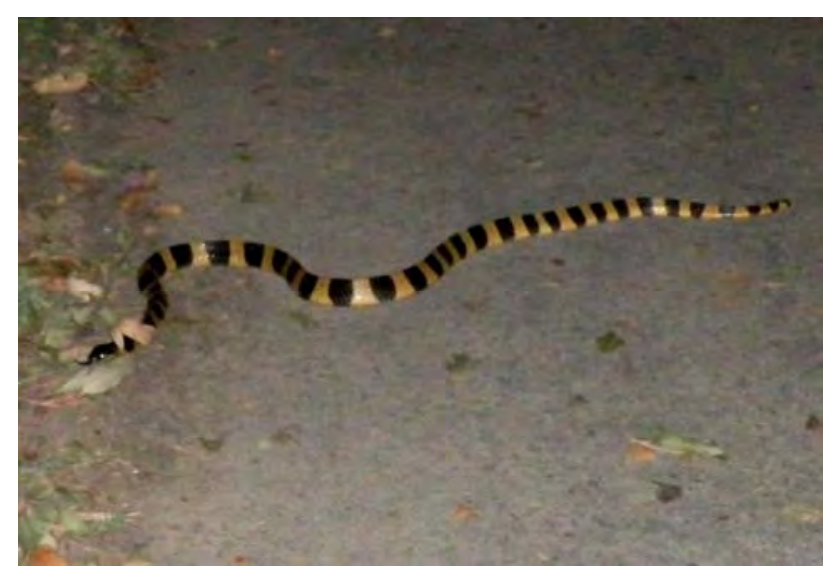

Fig. 1: Banded Krait, Bungarus fasciatus

There were crop fields on the both sides of the road bordered with a row of Syzygium cumini and some trees (Eucalyptus sp.). Depressions along the sides of the road meant for rain water storage for crop fields bears Lantana camara, Murraya koeinigii, Cassia sp. and Glycosmis pentaphylla - Shorea robusta dominated forest (Mahof range) is growing at a distance of $300 \mathrm{~m}$ from the sighting spot. Crop fields were witnessing the sowing of paddy at this time. These snakes have affinity with damp places, paddy fields and river sides. They are known to grow up to $180 \mathrm{~cm}$ (Wall, 1912), rarely up to 210 cm (Smith, 1911). The Terai region is known for forests inter-mixed with patchy grasslands and damp areas. This is the first report of this species from Pilibhit District which makes Pilibhit as its western most limits. Figure 1 shows the banding pattern, triangular body shape in cross-section and black crown, while Figure 2 shows the peculiar bluntly ending tail of the banded krait. Monocultures such as of Eucalyptus sp. and Tectona grandis, practiced in the grasslands of the Pilibhit forest threaten the natural habitats of the banded krait. 


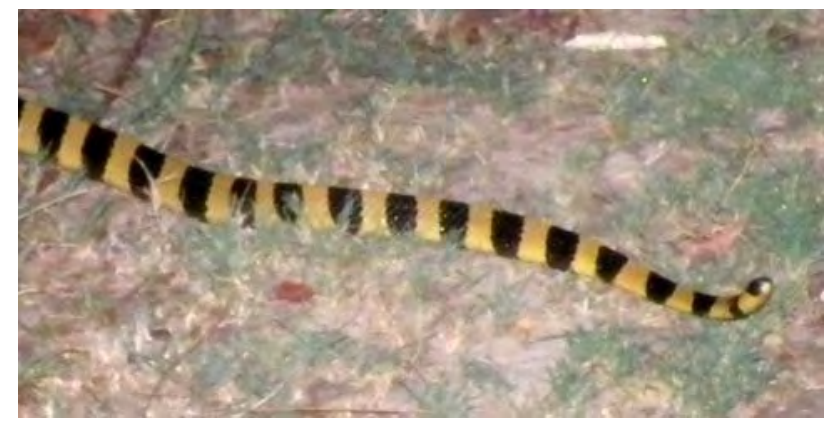

Fig. 2: The bluntly ending tail of the banded Krait

\section{Acknowledgements}

I wish to thank Ravi Singh, SG \& CEO of WWFIndia for providing resources, B. K. Patnaik, PCCF of Uttar Pradesh and V. K. Singh, D.F.O. of Pilibhit FD for permission and providing logistic support. We would like to acknowledge Dipankar Ghosh, Sejal Worah, Harish Kumar and Joseph Vattakavan for coordinating the tiger population monitoring exercise which provided me a chance to encounter this banded krait.

\section{Literature cited}

Acharji, M. N., 1946. A note on some snakes of Benaras. Journal of Bombay Natural History Society, 46: 344-347.

Daniel, J. C., 2002. The book of Indian reptiles and amphibians. BNHS-Oxford University Press, Mumbai: 238.

Deodars, P. J., 1978. Snakes of India. National Book Trust, India, New Delhi: 157.

Kinnear, N. B., 1913. Banded krait (Bungarus fasciatus) in Hyderabad state. Journal of Bombay Natural History Society, 22: 635-636.

Martin, S. J., 1913. Banded krait (Bungarus fasciatus) in Oudh. Journal of Bombay Natural History Society, 22: 635 .

Masson, J., 1929. The distribution of the banded krait (Bungarus fasciatus). Bombay Natural History Society, 34: 256-257.

Murthy, T. S. N., 2010. The reptile fauna of India. B.R. Publishing Corporation, Delhi: 331.

Sharma, R. C., 2003. Hand book - Indian Snakes. Zoological Survey of India, Kolkata: 292.

Smith, O. A., 1911. Large common and banded krait. Bombay Natural History Society, 21: 283-284.
Srinivasulu, G., D. Venkateshwarlu and M. Seethramaraju, 2009. Rediscovery of the Banded krait Bungarus fasciatus (Schneider 1801) (Serpentes: Elaspidae) from Warangal District, Andhra Pradesh, India. Journal of Threatened Taxa, 1: 353-354.

Wall, F., 1907. Notes on snakes collected in Fyzabad. Bombay Natural History Society, 18: 101-129.

Wall, F., 1910. Notes on snakes collected in upper Assam. Part II. Journal of Bombay Natural History Society, 19: 825-845.

Wall, F., 1912. A popular treatise on the common Indian snakes. Part 15. Bungarus fasciatus and Lycodon striatus. Journal of Bombay Natural History Society, 20: 933-953.

Whitaker, R. and A. Captain, 2004. Snakes of India, Draco Books, Chennai: 481.

Submitted: 10 August 2011, Accepted: 22 August 2011 Sectional Editor: Gernot Vogel

Meraj Anwar World Wide Fund for nature-India, 172-B, Lodi Estate, New Delhi 110003, India E-mail: anwar.meraj@gmail.com 